\title{
Schaduwgebieden van Europese regulering
}

\author{
L.A.J. Senden
}

\section{Inleiding}

De kaders waarbinnen nationale wet- en regelgeving tot stand komt, wordt toegepast en gehandhaafd, worden in toenemende mate bepaald door regels van internationale, transnationale en Europese herkomst. Dat levert een complex systeem van regulering en handhaving op, waarbij niet alleen internationale publiekrechtelijke verdragen inwerken op de nationale rechtsorde, maar ook allerlei transnationale private arrangementen steeds vaker invloed daarop uitoefenen. Voor EUlidstaten is die complexiteit nog groter, omdat ze ook nog te maken hebben met verschillende vormen van Europese regulering, die op hun beurt eveneens worden beïnvloed door internationale en transnationale regels. Bijgevolg moet de nationale wetgever opereren in een krachtenveld waarin verschillende externe normenstelsels niet alleen zelfstandig, maar ook in onderlinge verbinding effect sorteren op de nationale rechtsorde. Maar de juridische implicaties daarvan zijn lang niet altijd duidelijk.

In deze bijdrage worden drie trends geschetst op het terrein van Europese regulering die nogal ongrijpbaar zijn, omdat ze zich aftekenen in de schaduw van de formele normenhiërarchie die het Verdrag van Lissabon heeft geïntroduceerd. Het gaat daarbij onder meer om rechtsinstrumenten en vormen van delegatie en uitvoering die niet als zodanig in die normenhiërarchie zijn voorzien. De vraag die rijst, is hoe deze trends in het algehele Unierechtelijke systeem te begrijpen en te plaatsen zijn en wat voor consequenties ze met zich brengen voor de lidstaten en nationale autoriteiten. Deze bijdrage beoogt een tour d'horizon te geven en enkele pijnpunten bloot te leggen die in de toekomst nadere aandacht en discussie behoeven.

Allereerst wordt ingegaan op het formele Unie-instrumentarium, zoals dat door het Verdrag van Lissabon is vastgelegd (par. 2), en vervolgens op drie schaduwgebieden die geen plek hebben gekregen in dit instrumentarium noch in een ander deel van de Unieverdragen zijn geregeld (par. 3). Deze betreffen:

1 'zachte' bestuurlijke regelgeving door de Commissie;

2 bestuurlijke regelgeving door netwerken en verschillende Europese agentschappen;

3 de 'infiltratie' van private regulering in het Unierecht.

Vervolgens zal kort worden geschetst hoe deze trends passen binnen het onlangs herijkte Better Regulation-beleid van de Unie (par. 4). Ten slotte zal worden ingezoomd op de vraag welke consequenties de gesignaleerde ontwikkelingen mogelijkerwijs hebben voor nationale autoriteiten, met name de wetgever (par. 5). De bijdrage wordt afgerond met enkele slotbeschouwingen (par. 6). 


\section{De Europese normenhiërarchie post-Lissabon}

Het Verdrag van Lissabon heeft een normenhiërarchie aangebracht in de verschillende bindende, secundaire rechtshandelingen van de Europese Unie (hierna: EU) en daarmee tussen wetgeving en bestuurlijke regelgeving. Artikel 288 van het Verdrag betreffende de werking van de EU (VWEU) voorziet in het instrumentarium van de verordening, de richtlijn en het besluit, die elk de hoedanigheid van wetgevingshandeling, gedelegeerde handeling of uitvoeringshandeling kunnen aannemen (art. 289 t/m 291 VWEU). Ten aanzien van bestuurlijke regelgeving is aldus ook een nader onderscheid aangebracht tussen delegatie en uitvoering. ${ }^{1}$

Het onderscheid tussen de verschillende soorten handelingen berust op zowel procedurele als materiële verschillen:

1 Wetgevingshandelingen zijn handelingen die op basis van de gewone of een bijzondere wetgevingsprocedure zijn aangenomen en die essentiële onderdelen regelen, waarbij het VWEU overigens geen definitie biedt van wat als essentieel valt aan te merken.

2 Gedelegeerde handelingen betreffen de regeling van niet-essentiële onderdelen en worden op grond van delegatie door de Raad en het Europees Parlement (hierna: EP) door de Commissie aangenomen, waarbij de doelstellingen, inhoud, strekking en duur uitdrukkelijk moeten worden aangegeven. De Raad en het EP behouden de mogelijkheid de delegatie in te trekken of bezwaar aan te tekenen tegen de voorgenomen gedelegeerde handeling.

3 Uitvoeringshandelingen worden in beginsel door nationale autoriteiten getroffen, maar door de Commissie (soms de Raad) wanneer uitvoering volgens eenvormige voorwaarden geboden is. Daarbij dienen de voorgeschreven comitologieprocedures te worden gevolgd.

Op het eerste gezicht lijkt dit een allesomvattend en overzichtelijk systeem, maar er zitten verschillende haken en ogen aan. In de eerste plaats is het onderscheid tussen de verschillende handelingen vooral procedureel van aard, omdat het inhoudelijke criterium (essentieel/niet-essentieel) onvoldoende houvast biedt. De keuze voor het ene dan wel het andere instrument wordt daarmee meer politiek van aard, ingegeven door de mate van controle die men nog wenst te behouden ten aanzien van de regeling van een bepaalde kwestie. ${ }^{2}$ De keuze voor een gedelegeerde handeling maakt directe tussenkomst van de Europese wetgever mogelijk en wordt in die zin in ieder geval door het EP vaak geprefereerd boven een uitvoeringshandeling. ${ }^{3}$ Tegelijkertijd echter, hebben de lidstaten bij uitvoeringshandelingen meer mogelijkheden voor inhoudelijke sturing via de comitologieprocedu-

1 Zie ook T. Eijsbouts, J. Jans, A. Prechal \& L.A.J. Senden, Europees recht. Algemeen deel, Groningen: Europa Law Publishing 2015, p. 399-411.

2 Voor een concreet voorbeeld, zie T. van den Brink \& H. van Meerten, 'EU-bestuurlijke regelgeving in de praktijk: het IORP II Richtlijn-voorstel als voorbeeld', NtER 2015, afl. 4, p. 133-140.

3 Hierbij moet ook worden opgemerkt dat de procedure voorzien in art. 290 VWEU ter vervanging dient van de vroegere regelgevende comitologieprocedure met toetsing, die het EP de meest directe controlemogelijkheid bood ten aanzien van Commissiehandelingen. 
res, ${ }^{4}$ waardoor de Raad dan ook vaak een voorkeur voor uitvoeringshandelingen heeft. Om een maximale politieke controle op de Commissie te bewerkstelligen, verbaast het niet dat de Raad ook heeft aangestuurd op het onderwerpen van gedelegeerde handelingen aan consultaties van nationale experts. Vooralsnog zijn deze consultaties echter slechts informeel van aard en niet als zodanig geregeld in de Common Understanding on delegated acts, dat het EP, de Raad en de Commissie in 2011 hebben gesloten. ${ }^{5}$ Het Letse voorzitterschap heeft in 2014 wel aangedrongen op het daarin opnemen van een consultatieprocedure voor nationale experts, ${ }^{6}$ en in het kader van het nieuwe Better Regulation-beleid heeft de Commissie daarin voorzien in haar voorstel tot aanpassing van de Common Understanding. ${ }^{7}$

Ten tweede moet worden opgemerkt dat de normenhiërarchie zoals voorzien zeker geen volledig beeld schetst van het Unierechtelijk instrumentarium. De praktijk laat namelijk een breed scala aan instrumenten zien, maar ook delegatieen uitvoeringsvormen die in deze normenhiërarchie ontbreken en evenmin elders in de verdragen zijn geregeld.

\section{Drie schaduwgebieden}

\section{1 'Zachte' bestuurlijke regelgeving door de Commissie}

Het formele Uniesysteem voorziet nog steeds slechts summier in het soft lawinstrumentarium, dat inmiddels wel tot de standaarduitrusting van de EU behoort; artikel 288 VWEU noemt enkel aanbevelingen en adviezen als niet-bindende Unie-instrumenten, terwijl de Raad en de Commissie in het bijzonder ook gedragscodes, richtsnoeren, circulaires, mededelingen en bekendmakingen aannemen. Enerzijds gaat het daarbij om zachte sturingsinstrumenten die een zekere afstemming van nationale regelgeving of van nationaal beleid beogen, dat laatste vooral in combinatie met toepassing van de zogenaamde open methode van coördinatie. ${ }^{8}$ Dit krijgt dan veelal zijn beslag in aanbevelingen en gedragscodes. Anderzijds gaat het ook om zachte bestuurlijke regelgeving of beleidsregels, met name daar waar de Commissie richtsnoeren, aanbevelingen, mededelingen en

4 Verordening (EU) 182/2011 van het Europees Parlement en de Raad van 16 februari 2011 tot vaststelling van de algemene voorschriften en beginselen die van toepassing zijn op de wijze waarop de lidstaten de uitoefening van de uitvoeringsbevoegdheden door de Commissie controleren, PbEU 2011, L 55/13.

5 Te vinden op: <http://register.consilium.europa.eu/doc/srv?l=NL\&f=ST\%208753\%202011\%20 REV\%201>.

6 Zie <www.parlament.gv.at/PAKT/EU/XXV/EU/05/80/EU_58032/imfname_10534556.pdf >.

7 Zie de Annex bij het herziene voorstel voor een interinstitutioneel akkoord over betere regelgeving, gehecht aan de Better Regulation Guidelines, Commission Staff Working Document, SWD(2015)111 final, 19 mei 2015.

8 De open methode van coördinatie refereert aan een Europees gestuurd proces van coördinatie van nationaal beleid voor het realiseren van gemeenschappelijke beleidsdoelen, bijvoorbeeld ten aanzien van werkgelegenheid, die via nationale actieplannen, programma's en maatregelen moeten worden behaald. Zie daarover meer uitgebreid, L.A.J. Senden, 'Reguleringsintensiteit en regelgevingsinstrumentarium in het Europees gemeenschapsrecht. Over de relatie tussen wetgeving, soft law en de open methode van coördinatie', SEW (56) 2008, afl. 2, p. 43-57. 
bekendmakingen aanneemt met het oog op een correcte en uniforme interpretatie en toepassing van het Unierecht in de lidstaten.

In de meer recente praktijk zijn in dit verband enkele interessante ontwikkelingen te signaleren. Allereerst kan worden opgemerkt dat de zachte bestuurlijke regelgeving van de Commissie niet enkel meer louter interpretatief van aard is of indicatief van hoe ze haar eigen discretionaire beslissingsruimte inkleurt, maar soms ook richting beoogt te geven aan hoe de nationale autoriteiten te werk zouden moeten gaan bij de invulling van hun discretionaire ruimte bij de implementatie en toepassing van het Unierecht. ${ }^{9}$ Daarmee raakt de Commissie aan de nationale institutionele autonomie en met name de vrijheid van de lidstaten om zelf de vorm en middelen te bepalen ten aanzien van de omzetting van Europese richtlijnen.

Ten tweede krijgt de Commissie in wetgevingshandelingen van de Raad en het EP nogal eens de opdracht om zachte bestuurlijke maatregelen te treffen. Soms is die permissief of faciliterend van aard. Zo spreekt Richtlijn 2010/40 betreffende het kader voor intelligente vervoerssystemen in termen van 'De Commissie kan richtsnoeren en andere niet-bindende maatregelen vaststellen ter bevordering van de samenwerking tussen de lidstaten op de prioritaire gebieden (...) ${ }^{10}$ (curs. LS). In andere gevallen echter, is zo'n opdracht dwingend van toon. Dat betreft bijvoorbeeld Richtlijn 2011/24 betreffende de toepassing van rechten van patiënten bij grensoverschrijdende gezondheidszorg, die bepaalt dat de 'Commissie richtsnoeren vast stelt om de lidstaten te ondersteunen bij het ontwikkelen van de interoperabiliteit van elektronische recepten'11 (curs. LS). Zo geformuleerd ontstaat er feitelijk een secundairrechtelijke plicht voor de Commissie tot het aannemen van niet-bindende handelingen die als zodanig niet voorzien zijn in het primaire Unierecht. $\mathrm{Nu}$ het bovenal gaat om maatregelen die bijdragen aan een eenvormige toepassing van het Unierecht in de lidstaten, kunnen ze qua doelstelling wel worden gesitueerd in de context van de in artikel 291 VWEU aan de Commissie geattribueerde uitvoeringsbevoegdheden. De juridische status en werkingssfeer van dergelijke niet-bindende uitvoeringshandelingen blijven echter onduidelijk, met name de verplichtingen die deze al dan niet met zich brengen voor nationale autoriteiten. Ook is onduidelijk aan welke democratische en procedurele waarborgen de aanname daarvan moet voldoen (nader hierover par. 5).

Een derde belangrijke ontwikkeling betreft het feit dat de aanname van - harde en zachte - bestuurlijke regelgeving niet meer het uitsluitende prerogatief is van de Commissie, maar in toenemende mate ook tot het takenpakket behoort van Europese netwerken en agentschappen. Dat brengt mij tot het volgende schaduwgebied.

9 Bijv. Oriëntatiedoc. AGRI/60363/2005-RevI. Nader hierover H. Luijendijk \& L.A.J. Senden, 'De gelaagde doorwerking van Europese administratieve soft law in de nationale rechtsorde. Preadvies voor Nederlandse Vereniging voor Europees Recht', SEW (59) 2011, afl. 7-8, p. 317.

10 Art. 9 van Richtlijn 2010/40 betreffende het kader voor het invoeren van intelligente vervoerssystemen op het gebied van wegvervoer en voor interfaces met andere vervoerswijzen, $\mathrm{PbEU}$ 2010, L 207/1. Zie art. 23(4) van Richtlijn 2010/63 voor een vergelijkbaar voorbeeld.

11 Art. 11(2)a van Richtlijn 2011/24, PbEU 2011, L 88/45. 


\subsection{Bestuurlijke regelgeving door netwerken en agentschappen}

Europese netwerken, zoals die bijvoorbeeld tot stand zijn gekomen op de terreinen van mededinging, telecommunicatie en milieu, zijn bovenal gericht op de effectieve toepassing en handhaving van Europese rechtsregels in de lidstaten. ${ }^{12}$ Als zodanig zijn ze ook wel getypeerd als Trojaanse paarden die een centralisering van toezicht op Unieniveau met zich brengen en waarbij nationale toezichthouders feitelijk als een verlengstuk van de EU opereren. ${ }^{13}$ Hier is met name van belang op te merken dat deze netwerken ook zachte beleidsregels aannemen. Dat geldt niet alleen voor de moeder van alle Europese netwerken, het Europees Mededingingsnetwerk, maar bijvoorbeeld ook voor het e-gezondheidsnetwerk, in de oprichting waarvan de hiervoor genoemde Richtlijn 2011/24 voorzag. Dit netwerk heeft zelfs als nadrukkelijk doel de opstelling van richtsnoeren, onder meer aangaande het opstellen van een niet-exhaustieve lijst van gegevens die in patiëntendossiers moeten worden opgeslagen en die door gezondheidswerkers kunnen worden gedeeld, zodat ook over de grens heen zorgcontinuïteit en patiëntveiligheid kunnen worden gewaarborgd. ${ }^{14}$

Europese agentschappen komen in verschillende soorten en maten voor, maar hier gaat het om die agentschappen die een bestuurlijke regelgevingsbevoegdheid uitoefenen. Dat was reeds het geval bij enkele al wat oudere agentschappen, zoals EASA (Europees Agentschap voor de veiligheid van de luchtvaart), dat op grond van zijn oprichtingsverordening technische richtsnoeren mag aannemen en waarvan de naleving is onderworpen aan de comply or explain-regel. ${ }^{15}$ De EMA (Europees Geneesmiddelen Agentschap) is een voorbeeld van een agentschap dat de facto technische, wetenschappelijke en procedurele richtsnoeren is gaan aannemen, zonder dat in een formele bevoegdheid daartoe is voorzien. ${ }^{16}$ Deze ontwikkeling is echter pas echt goed op gang gekomen met de oprichting van de drie financiële toezichthoudende agentschappen in 2011: de EBA (Europese Bankenautoriteit), ESMA (Europese Autoriteit voor effecten en markten) en EIOPA (Europese Autoriteit voor verzekeringen en bedrijfspensioenen). Deze drie agentschappen hebben langs verschillende wegen een belangrijke reguleringstaak toebedeeld gekregen.

Ten eerste hebben ze de bevoegdheid om ontwerpregelingen aan de Commissie voor te stellen voor technische normen. Daarnaast voorzien hun oprichtingsver-

12 Zie uitgebreid M. de Visser, Network-Based Governance in the EU, Oxford: Hart Publishing 2009.

13 A. de Moor-van Vugt, 'Netwerken en de europeanisering van het toezicht', SEW 2011, p. 100.

14 Art. 14 lid 2. Zie over dit netwerk ook COM(2012)736 final.

15 Art. 18(c) en 19(2)(b) van Verordening 216/2008 van het EP en de Raad van 20 februari 2008 tot vaststelling van gemeenschappelijke regels op het gebied van burgerluchtvaart en tot oprichting van een Europees Agentschap voor de veiligheid van de luchtvaart, PbEU 2008, L 79/1.

16 Zie E. Chiti, 'European Agencies' Rule-Making. Powers, Procedures and Assessment', European Law Journal (19) 2013, afl. 1 p. 102. 
ordeningen $^{17}$ in de taak om richtsnoeren en aanbevelingen te richten aan bevoegde autoriteiten en/of financiële instellingen met het oog op het invoeren van consistente, efficiënte en effectieve toezichtpraktijken in de gehele Unie en het verzekeren van de gemeenschappelijke, uniforme en consistente toepassing van het Unierecht. ${ }^{18}$ In het bijzonder dienen de agentschappen via de uitoefening van deze reguleringstaak bij te dragen aan de invoering van kwalitatief hoogstaande gemeenschappelijke regulerings- en toezichtnormen en -praktijken in de lidstaten. ${ }^{19}$ In afzonderlijke verordeningen worden concrete verplichtingen opgelegd tot het aannemen van richtsnoeren en aanbevelingen, maar er is ook ruimte voor eigen initiatief. ${ }^{20}$ De agentschappen spelen dus een actieve rol in het opbouwen van een gemeenschappelijke toezichtcultuur van de Unie en consistente toezichtpraktijken, alsmede in het verzekeren van uniforme procedures in de gehele Unie. Daartoe moeten ze ook de toepassing evalueren van de door de Commissie vastgestelde normen en van de eigen richtsnoeren en aanbevelingen, en waar nodig wijzigingen voorstellen. ${ }^{21}$ Daarbovenop heeft de Uniewetgever ESMA zelfs de bevoegdheid gegeven om ook juridisch bindende besluiten van een algemene strekking aan te nemen, die besluiten van een bevoegde nationale autoriteit kunnen vervangen. Een dergelijke ESMA-maatregel heeft zelfs uitdrukkelijk voorrang op alle door een bevoegde nationale autoriteit genomen maatregelen. ${ }^{22}$

De vraag rijst hoe deze bestuurlijke regelgevingsbevoegdheid zich verhoudt tot die van de Commissie. Een eerste constatering in dit verband is dat de agentschappen een belangrijke voorbereidende rol blijken te spelen ten aanzien van de gedelegeerde en uitvoeringshandelingen die de Commissie op grond van de artikelen 290 en 291 VWEU aanneemt. De ontwerpregelingen van de agentschappen voor technische regulerings- en uitvoeringsnormen krijgen namelijk uiteindelijk hun beslag in een dergelijke Commissiehandeling. Feitelijk impliceert die voorbereidende taak van de desbetreffende agentschappen dus een soort van subdelegatie daaraan. Een tweede constatering is dat de agentschappen via de aanname van richtsnoeren en aanbevelingen ook een meer zelfstandige regelgevende functie vervullen, parallel aan en vergelijkbaar met de zachte bestuurlijke regelgeving die de Commissie zelf aanneemt en die gericht is op een goede, consistente en uniforme toepassing van het Unierecht. En een derde constatering is dat de Uniewetgever er klaarblijkelijk van uitgaat dat niet alleen de Raad en de Commissie

17 Verordening 1093/2010 van het EP en de Raad tot oprichting van een Europese toezichthoudende autoriteit (EBA), PbEU 2010, L 331/12, Verordening 1094/2010 van het EP en de Raad tot oprichting van een Europese toezichthoudende autoriteit (EIOPA), PbEU 2010, L 331/48 en Verordening 1095/2010 van het EP en de Raad tot oprichting van een Europese toezichthoudende autoriteit (ESMA), PbEU 2010, L 331/84.

18 Zo spreekt art. 16 EBA-Verordening in termen van 'de Autoriteit richt aanbevelingen en richtsnoeren tot bevoegde autoriteiten of financiële instellingen'.

19 Zie bijv. art. 8 en punt 26 van de preambule van de EBA-Verordening.

20 Zie M. van Rijsbergen, 'On the Enforceability of Agencies' Soft Law at the National Level: The Case of the European Securities and Markets Authority', Utrecht Law Review 2014, p. 121.

21 Vgl. art. 29 lid 1 EBA-Verordening.

22 Zie Verordening 236/2012 betreffende short selling en bepaalde aspecten van kredietverzuimswaps, $P b E U$ 2012, L 274/1, in het bijzonder art. 28 daarvan. 
bevoegd zijn om juridisch bindende besluiten van algemene strekking aan te nemen, maar dat ook andere Unieorganen een dergelijke bevoegdheid toebedeeld kan worden.

De logische vervolgvraag is dan hoe deze ontwikkelingen binnen de constitutionele grondslagen van de Unie passen. De Europese verdragen reppen immers nergens in zoveel woorden over de rol en taakstelling van agentschappen binnen het Europese institutionele bestel, niet als onderdeel van de normenhiërarchie en delegatiesystematiek in de artikelen 288 t/m 291 VWEU, noch elders. Wel heeft het Verdrag van Lissabon voorzien in mogelijkheden van rechtsbescherming tegen handelingen van 'organen en instanties van de Unie', waaronder agentschappen, in het kader van verschillende gerechtelijke procedures. Daarmee is er een vooronderstelling dat ze individuele besluiten met rechtsgevolgen kunnen nemen of regelgevingshandelingen kunnen vaststellen in de zin van de procedure tot nietigverklaring (art. 263 VWEU). Maar van een uitdrukkelijke, formele machtiging aan agentschappen om dergelijke besluiten of regels van algemene strekking aan te nemen en onder welke voorwaarden dat het geval is, is dus geen sprake.

Op basis van de rechtspraak van het Hof van Justitie EU is ook jarenlang gedacht dat een dergelijke bevoegdheid uitgesloten was. Zo stelde het Hof in de Meronizaak vast dat weliswaar bevoegdheden kunnen worden gedelegeerd aan externe instellingen, maar deze geen ruime discretionaire bevoegdheid mogen impliceren die een vrijheid van waardering met zich brengt die aan de Brusselse instellingen is voorbehouden. ${ }^{23}$ In de Romano-zaak stelde het Hof dat een door de Europese Gemeenschap bij verordening opgerichte administratieve commissie voor de sociale zekerheid van migrerende werknemers niet door de Raad kon worden gemachtigd om normatieve besluiten te nemen. ${ }^{24}$ Naast de nieuwe normenhiërarchie vormde deze rechtspraak voor het Verenigd Koninkrijk dan ook een belangrijke reden om de juridisch verbindende regelgevende bevoegdheden van ESMA te betwisten in een procedure voor het Hof. ${ }^{25}$ Dit concludeerde echter dat de delegatie c.q. attributie van regelgevende bevoegdheden aan ESMA rechtmatig was, gegeven dat:

- ESMA een Unierechtelijke instantie is;

- er geen sprake is van autonome bevoegdheden die het regelgevingskader van de ESMA-verordening te buiten gaan;

- de bevoegdheden onderworpen zijn aan verschillende criteria en voorwaarden die de speelruimte van ESMA beperken; en

- het door het VWEU vastgestelde institutionele kader, zoals met name vervat in de artikelen 263, 265, 267 en 277 VWEU, de organen en instanties van de Unie uitdrukkelijk de mogelijkheid biedt of de vooronderstelling bevat om handelingen van algemene strekking vast te stellen. 
Daaruit leidt het Hof feitelijk af dat, ook al wordt nergens in de verdragen voorzien in de verlening van bevoegdheden aan een Unieorgaan of -instantie, de verdragsopstellers met de artikelen 290 en 291 VWEU niet 'één enkel rechtskader hebben willen vaststellen op grond waarvan bepaalde gedelegeerde uitvoerende bevoegdheden uitsluitend aan de Commissie kunnen worden toegewezen, maar dat de wetgever van de Unie andere systemen voor het delegeren van dergelijke bevoegdheden aan organen of instanties van de Unie in overweging kan nemen' (curs. LS). Artikel 114 VWEU vormt volgens het Hof een geldige rechtsgrondslag voor de verordening die ESMA deze bevoegdheden geeft. ${ }^{26}$

Het belang van en de juridische ruimte voor bestuurlijke regelgevende bevoegdheden van agentschappen (en mogelijkerwijs andere 'organen en instanties' van de Unie) groeien dus gestaag en het betreft niet enkel formeel zachte, maar nu ook uitdrukkelijk bindende regelgeving. Uit de ESMA-uitspraak (met name bovenstaand citaat) kan echter wel worden opgemaakt dat het bij dit laatste alleen kan gaan om harde uitvoeringsregelgeving. Subdelegatie door de Commissie van de haar in het kader van artikel 290 VWEU gedelegeerde bevoegdheid aan een agentschap zou onrechtmatig zijn, omdat dat raakt aan wijziging van de normatieve inhoud van een wetgevingshandeling. ${ }^{27}$ In dit verband kan het dus enkel gaan om zachte ontwerpregelingen van agentschappen. ${ }^{28}$ Niettegenstaande dit onderscheid draagt het oordeel van het Hof eraan bij dat er feitelijk sprake is en blijft van een behoorlijk smalle constitutionele basis voor bestuurlijke regelgeving van allerlei Unieorganen en -instanties, zeker wanneer we de mogelijke consequenties voor nationale autoriteiten in ogenschouw nemen (zie par. 5). Daar waar uitvoeringsbevoegdheden in de zin van artikel 291 VWEU nog wel zo kunnen worden uitgelegd dat die ook zachte bestuurlijke handelingen van de Commissie omvatten, is dat een brug te ver voor - harde en zachte - bestuurlijke regelgeving van agentschappen, omdat deze bepaling in het geheel niet voorziet in uitvoeringsbevoegdheden voor dit soort organen, laat staan dat die in algemene zin onderworpen zijn aan controle van de lidstaten via het comitologiesysteem. Agentschappen en andere Unie-instanties kunnen dus regelgevende uitvoeringsbevoegdheden worden toegekend enkel op basis van een 'materiële' verdragsbepaling, zonder dat voor de uitoefening daarvan algemene, procedurele randvoorwaarden en waarborgen gelden. De mogelijkheid van ex post rechterlijke controle wordt klaarblijkelijk als voldoende beschouwd, maar daar zitten nogal wat beperkingen aan. ${ }^{29}$

26 Zie voor een nadere bespreking van deze zaak M. Scholten \& M. van Rijsbergen, Zaak C-270/12 (ESMA-short selling) als opvolger van de Meroni- en Romano-non-delegatiedoctrine, NtER 2014, afl. 2-3.

27 Vgl. punten 84-87 van de concl. van A-G Jaäskinen in de ESMA-zaak, 12 september 2013, ECLI:EU:C:2013:562.

28 Zij het dat hier ook zeker een constitutionele kanttekening op haar plaats is, aangezien de Commissie dergelijke regelingen nogal eens 'rubberstamps'. Zie L.A.J. Senden \& T. van den Brink, 'Checks and Balances of Soft EU-Rulemaking', 2012, rapport voor het EP, PE 462.433, p. 43.

29 Zoals de locus standi-voorwaarde dat men moet kunnen aantonen dat een handeling rechtsgevolgen beoogt te hebben. Nader over deze beperkingen Senden \& Van den Brink 2012, p. 68-70. 


\subsection{De 'infiltratie' van private regulering in het Unierecht}

Het voorgaande betrof de bespreking van ontwikkelingen op het niveau van regulering door publieke EU-actoren en de verhouding daarvan tot het formele instrumentarium en de constitutionele grondslagen van de Unie. Daarnaast echter kan worden gesignaleerd dat ook private actoren langs verschillende wegen invloed doen gelden op zowel zachte als harde Uniewet- en -regelgeving. Staten worden dus niet alleen direct geconfronteerd met normen die rechtstreeks afkomstig zijn uit een transnationale, private bron, maar ook via de weg van het Unierecht. ${ }^{30}$ In het eerste geval kunnen ze zelf nog bepalen welk belang daaraan te geven, maar in het laatste geval gebeurt dit in de context van het Europese besluitvormingsproces.

Dit gebeurt allereerst op het terrein van harmonisatie en technische standaardisatie, ten aanzien waarvan de EU sinds 1985 de zogenaamde 'nieuwe aanpak' volgt. Deze nieuwe aanpak betreft de vaststelling van Europese normen door Europese normalisatie-instituten (CEN, CENELEC en ETSI), onafhankelijke privaatrechtelijke organisaties. Volgens de Commissie zijn de door deze instituten vastgestelde normen

'vrijwillige documenten met technische of kwalitatieve voorschriften waaraan bestaande of toekomstige producten, productieprocessen, diensten of methoden kunnen voldoen. Zij zijn het resultaat van vrijwillige samenwerking tussen bedrijven, overheden en andere belanghebbende partijen in een systeem dat op openheid, transparantie en consensus berust.'31

Naleving van een dergelijke norm is niet verplicht, maar naleving veronderstelt wel dat daarmee is voldaan aan de harde, essentiële eisen die in EU-richtlijnen worden gesteld, bijvoorbeeld aangaande productveiligheid. In het licht van het toenemend belang van technische normen, zeker in mondiaal perspectief, is in recente jaren de nieuwe aanpak uitgebreid en zijn de (ook juridische) uitgangspunten en randvoorwaarden ervan herzien (zie ook par. 5). ${ }^{32}$ Hier is van belang op te merken dat in deze herziening een sterke nadruk is gelegd op het bevorderen van de samenwerking met internationale normalisatie-instituten, zoals met de Internationale Organisatie voor Standaardisatie (ISO). Dit met het oog op het bewerkstelligen van zo veel mogelijk convergentie van regelgeving in de huidige wereldmarkten. Convergentie impliceert enerzijds erkenning van het primaat van internationale normen die door deze instituten zijn vastgesteld en het waar

30 Zie o.m. F. Cafaggi, C. Scott \& L.A.J. Senden, 'The Challenge of Transnational Private Regulation: Conceptual and Constitutional Debates', Journal of Law and Society (38) 2011, afl. 1 (Special Issue) en J. Zeitlin (red.), Extending Experimentalist Governance? The European Union and Transnational Regulation, Oxford: Oxford University Press 2015.

31 Mededeling van de Commissie, 'Een strategische visie voor Europese normen: de duurzame groei van de Europese economie tussen nu en 2020 bevorderen en versnellen', COM(2011)311 def., p. 1.

32 Ibid. en Verordening 1025/2012 van het EP en de Raad betreffende Europese normalisatie, tot wijziging van een aantal richtlijnen en tot intrekking van beschikking en besluit op dit terrein, PbEU 2012, L 316/12. 
mogelijk voortbouwen en baseren van Europese normen daarop. Anderzijds impliceert zij ook een proactieve houding en acties van de Europese normalisatieinstellingen om zelf internationale normen voor te stellen.

Maar ook buiten het terrein van technische standaardisatie wint private regulering in de EU-context aan belang, met name daar waar Europese wetgeving private regulering direct van toepassing verklaart. Een concreet voorbeeld betreft de bepaling in de Europese verordening inzake de bescherming van dieren tijdens vervoer en aanverwante activiteiten, dat de lidstaten ervoor moeten zorgen dat luchtvervoerders de Live Animals Regulations in acht nemen die IATA (International Air Transport Association) heeft opgesteld. ${ }^{33}$ Een dergelijke transnationale private regeling krijgt aldus de status van een juridisch bindende, EU-publiekrechtelijke norm, ten aanzien waarvan alle lidstaten nakoming en toepassing dienen te verzekeren als het gaat om het vervoer van levende dieren per vliegtuig. Hoewel men zou kunnen redeneren dat een dergelijke bindende werking (in ieder geval formeel) wel democratisch gelegitimeerd is wanneer zo'n regeling is vervat in een Europese wetgevingshandeling (immers aangenomen door het EP en de Raad), is de inhoudelijke beoordeling van dergelijke private normen zeer marginaal en is er van directe betrokkenheid bij de opstelling daarvan geen sprake. Wanneer een gedelegeerde of uitvoeringshandeling van de Commissie een dergelijke verwijzing bevat, dan is zelfs die formele democratische legitimatie niet gewaarborgd. Veel zal dan afhangen van het proces waarbinnen de private norm als zodanig tot stand is gekomen en welke actoren daarbij betrokken zijn. Een ander voorbeeld betreft private normen als maatstaf in toezichtprocedures, ter beoordeling of voldaan is aan Europese wettelijke normen. Zo hanteert EASA als een van de drie criteria voor het toelaten van vliegtuigen tot het Europese luchtruim, dat deze hebben voldaan aan IATA-audits die zijn uitgevoerd op basis van normen die door IATA zelf zijn opgesteld.

\section{EU-beleid inzake betere regelgeving}

De gesignaleerde ontwikkelingen kunnen allereerst worden beschouwd vanuit een institutioneel EU-perspectief; welke factoren spelen vanuit dit perspectief eigenlijk een rol bij de instrumentkeuze? Enerzijds kan worden opgemerkt dat de keuze voor een bepaald instrumentarium wordt bepaald door externe factoren, zoals tijd en plaats. Anderzijds zijn er echter meer interne, systeemspecifieke factoren die daarin een belangrijke rol spelen, waarbij het vooral gaat om bestaande politieke en machtsconstellaties en preferenties voor bepaalde beleidsdoelen en reguleringsstrategieën. In de Uniecontext is sinds jaar en dag sprake van een sterke integration through law-aanpak, waarbij de Europese verdragen op veel beleidsterreinen wijzen op een taak voor de Europese wetgever om de gestelde doelen via wetgeving te realiseren. Wel is er sinds de jaren negentig een meer gedifferentieerde of multi-level governance-aanpak ontwikkeld, onder andere als gevolg van de verschillende verdragswijzigingen die bepaalde beleidsterreinen 
weliswaar binnen Uniebereik brachten, maar soms slechts met het oog op beleidscoördinatie en niet met het oog op harmonisatie of uniformering van wetgeving. Dit betreft de terreinen van aanvullende, ondersteunende c.q. coördinerende competentie die nu in de artikelen 5 en 6 VWEU zijn geregeld en die harmonisatie zelfs uitsluiten. Maar op de terreinen van exclusieve Uniecompetentie en gedeelde bevoegdheden van de EU en de lidstaten vormen recht en regelgeving nog steeds het primaire integratie-instrument boven allerlei andere (economische, fiscale) sturingsinstrumenten, waarbij het terrein van de Economische en Monetaire Unie (EMU) inmiddels wel een bijzondere positie inneemt. Gaat het om gedeelde bevoegdheden, dan hangt het van subsidiariteits- en proportionaliteitsoverwegingen af of en in welke mate de Unie optreedt.

De Commissie en het EP hebben vanuit hun eigen institutionele positie bezien vaak een groot belang bij het gebruik van wetgeving, maar de Commissie kan haar invloed ook vergroten via het gebruik van allerlei soft law-instrumenten, wat ten koste kan gaan van de positie van de Europese wetgever. ${ }^{34} \mathrm{Bij}$ de instrumentkeuze speelt ook een rol om welke Uniebevoegdheid het gaat en of de desbetreffende rechtsgrondslagen een bepaald instrument voorschrijven of meer algemeen spreken van 'maatregelen' die moeten worden genomen. In dat laatste geval is er meer ruimte voor een proportionaliteitsafweging, niet alleen voor wat betreft de inhoud, maar ook voor wat betreft de vorm daarvan. Overigens is de rechterlijke controle ten aanzien van de keuze van het instrument beperkt, ook als het gaat om die tussen gedelegeerde en uitvoeringshandelingen. ${ }^{35}$

Het nieuwe Better Regulation-beleid dat deze zomer door de daarvoor verantwoordelijke Commissaris, Frans Timmermans, is gepubliceerd, kenmerkt zich door een veelomvattende benadering. Het stelt namelijk een gedeelde verantwoordelijkheid voor betere regelgeving van de Unie en nationale instellingen voorop en wijst op het belang dit ten aanzien van alle onderdelen van de beleidscyclus te verzekeren en om stakeholders daarbij te betrekken. 'Betere regelgeving' impliceert dus niet alleen dat vooraf de nodige toetsing van beleidsdoelstellingen en reguleringsstrategieën c.q. instrumenten plaatsvindt via impact assessments, maar ook dat implementatie, monitoring en ex-postevaluatie worden gerealiseerd. Met betrekking tot de keuze van het instrumentarium is het uitgangspunt van de Commissie dat 'bij het onderzoeken van beleidsoplossingen [wordt gekeken] naar zowel regelgevende maatregelen als goed doordachte niet-regelgevende instrumenten (...)'. ${ }^{36}$ Uit de Better Regulation Guidelines en de Toolbox, die een nadere uitwerking bevatten, blijkt dat de keuze van het instrumentarium bovenal wordt gezien als een onderdeel van de impact assessments, met name de proportionaliteitsafweging die in dat verband moet worden gemaakt. Tool 15 onderscheidt

34 Dit verklaart ook ten dele in ieder geval de kritische houding van het EP ten aanzien van het gebruik van soft law; zie de resolutie van het EP van 4 september 2007 over de institutionele en juridische gevolgen van het gebruik van 'soft law'-instrumenten (2007/2028(INI)), P6_TA(2007)0366.

35 Zie zaak C-427/12, ECLI:EU:C:2014:170 (Commissie/Europees Parlement en Raad) (Biociden).

36 Mededeling van de Commissie, 'Betere regelgeving voor betere resultaten - een EU-agenda', COM(2015)215 final, p. 6. 
in dit verband 'harde' juridisch verbindende regels, 'zachte' regulering, onderwijs en informatievoorziening en economische instrumenten. Opvallend is dat bij de harde regulering geen onderscheid wordt gemaakt tussen wetgeving en bestuurlijke regelgeving, maar alleen de artikel 288 VWEU-instrumenten worden beschreven. Bij de zachte regulering valt op dat wel naar zelf- en coregulering, technische standaarden, aanbevelingen en de open methode van coördinatie wordt gewezen, maar niet naar enige vorm van zachte bestuurlijke regelgeving van de Commissie, netwerken en agentschappen, zoals besproken in deze bijdrage. Het nieuwe beleid biedt aldus geen verduidelijking van de rol van en keuze voor zachte bestuurlijke regelgeving, aanbevelingen uitgezonderd, en evenmin van de toepasselijkheid van de betere regelgevingseisen waar deze aan moet voldoen. Wat de harde bestuurlijke regelgeving betreft beperkt het beleid zich vooral tot een herziening van de eerdergenoemde Common Understanding voor het gebruik van gedelegeerde handelingen. De harde uitvoeringsstaak die zoals gebleken aan agentschappen kan worden toebedeeld, is hierbij buiten beschouwing gebleven.

\section{Gevolgen voor nationale autoriteiten}

De vraag hoe de Nederlandse wetgever met al deze instrumenten en normen moet omgaan, is niet eenvoudig te beantwoorden. De bepaling in artikel 291 VWEU is richtinggevend in de zin dat de lidstaten (enkel) verplicht zijn om 'alle maatregelen van intern recht [te nemen] die nodig zijn ter uitvoering van de juridisch bindende handelingen van de Unie' (curs. LS). Strikt genomen zijn lidstaten dus niet verplicht om gevolg te geven aan zachte bestuurlijke regelgeving van de Commissie. Gegeven de brede formulering van deze bepaling geldt dit ook voor niet-bindende handelingen van andere Unie-instellingen, -instanties en -organen, agentschappen en netwerken incluis. Maar daarmee is het dilemma voor de nationale wetgever niet opgelost. Het advies van de Afdeling advisering van de Raad van State over de ETS-richtsnoeren en de reactie daarop van de staatssecretaris van Infrastructuur en Milieu illustreren dit. ${ }^{37}$ Het ontwerpbesluit ter wijziging van het Besluit handel in emissierechten voorzag ten dele in een omzetting van de 'Guidance on Interpretation of Annex I of the EU ETS Directive' van de Commissie van 18 maart 2010. De Afdeling was van mening dat daarmee een juridisch bindende werking aan onderdelen van deze richtsnoeren werd gegeven die het Unierecht niet vereist en ook niet wenselijk is. Daarbij wees de Afdeling op de onnodige beperking die dat op zou leggen aan de uitvoeringspraktijk en op het feit dat de richtsnoeren afkomstig zijn van een groep experts, geen open besluitvormingsprocedure is gevolgd, niet voldaan is aan het kenbaarheidsvereiste en de richtsnoeren mogelijk in de toekomst aanpassing behoeven. Volgens de staatssecretaris omvatten de richtsnoeren elementen die rechten en verplichtingen met zich brengen, die omwille van de rechtszekerheid, uitvoerbaarheid en handhaaf-

37 Advies W14.14.0115/IV, 5 juni 2014 en nader rapport I\&M/BSK 214/192323, 13 oktober 2014, te vinden op: <www.raadvanstate.nl/adviezen/zoeken-in-adviezen/tekst-advies.html?id=11425>. 
baarheid hun beslag dienen te krijgen in een algemeen verbindende regeling. In die zin zou het niet gaan om het gehoor geven door de nationale wetgever aan een veronderstelde omzettingsplicht, maar om een nationale behoefte aan verduidelijking. Feit is echter wel dat de uitkomst uiteindelijk hetzelfde is; onderdelen van de Commissierichtsnoeren worden door opname in een nationale bindende regeling alsnog harde normen die door de vergunningverlenende instantie moeten worden toegepast. Ook op andere terreinen, zoals dat van subsidieverlening, vindt zachte bestuurlijke regelgeving van de Commissie haar weg naar Nederlandse wetgeving. ${ }^{38}$

In een eerdere en uitvoerigere bijdrage ${ }^{39}$ met Luijendijk is in dit verband geconstateerd dat de Nederlandse wetgever niet alleen bij implementatie van secundair EU-recht in nationale wetgeving naar Europese beleidsregels verwijst, maar ook bij de vormgeving van autonoom beleid. Een drijfveer daarvoor kan zijn het voorkomen dat de Commissie een verdragsinbreukprocedure tegen Nederland start. In de Nederlandse wetgevingspraktijk zijn grosso modo vier methoden te onderscheiden waarlangs de Nederlandse wetgever werking geeft aan zachte Commissieregels, te weten overname, verwijzing, uitleg en inspiratie. Bij een uitleg- of inspiratieverwijzing in de toelichting bij de wetgeving blijft een van de Europese regel afwijkende uitleg het makkelijkst mogelijk. Overname of verwijzing is aan de orde ingeval er sprake is van een verplichtende situatie. Dat is het geval wanneer er een specifieke samenwerkingsplicht bestaat en Nederland heeft ingestemd met de regel. Dan ontstaat er wel een verplichting voor de lidstaat hieraan te voldoen. Dat betreft met name het terrein van staatssteun. Soms ook bevat secundair EUrecht een inspanningsverplichting om de door de Commissie opgestelde zachte regels in aanmerking te nemen, ${ }^{40}$ waarbij de wetgever zal moeten kunnen motiveren waarom in voorkomend geval een andere koers is gevaren. ${ }^{41}$ Maar ook wanneer dit niet aan de orde is, kiest de wetgever soms voor verwijzing of overname in de wetgeving zelf, zoals het voorbeeld van de ETS-richtsnoeren laat zien. Bij de wenselijkheid daarvan kunnen vraagtekens worden gezet, gelet op het feit dat de democratische basis van de Europese regel vaak erg smal is. ${ }^{42}$ Deze zorg spreekt ook uit bovenstaande overwegingen van de Raad van State ter zake van de ETS-

38 Zie daarover C. van Dam, 'De doorwerking van Europese administratieve soft law: in strijd met Nederlandse legaliteit?', Netherlands Administrative Law Library, januari 2013, te vinden op: <www.nall.nl/tijdschrift/nall/2013/01/NALL-D-12-00008/fullscreen>.

39 Luijendijk \& Senden 2011.

40 Zie o.m. art. 15 lid 3 Richtlijn 2002/21/EG van 7 maart 2002 inzake een gemeenschappelijk regelgevingskader voor elektronische-communicatienetwerken en -diensten (Kaderrichtlijn), PbEG 2002, L 108/33: 'De nationale regelgevende instanties bepalen, zoveel mogelijk rekening houdend met de aanbeveling en de richtsnoeren, de relevante markten die overeenkomen met de nationale omstandigheden, met name relevante geografische markten binnen hun grondgebied, overeenkomstig de beginselen van het mededingingsrecht' (curs. LS). Ingevolge art. 16 lid 5: '(...) dragen de betrokken nationale regelgevende instanties samen zorg voor de uitvoering van de marktanalyse, waarbij zoveel mogelijk rekening wordt gehouden met de richtsnoeren (...)' (curs. HL \& LS).

41 Zie zaak C-11/05, ECLI:EU:C:2006:312 (Friesland Coberco Dairy Foods), r.o. 34-42.

42 Bij overname of verwijzing in nationale wetgeving geldt eveneens dat voor zover er democratische controle is, deze formeel is en niet meer op een inhoudelijke beoordeling is gericht. 
richtsnoeren. Verder staat de verenigbaarheid van dergelijke richtsnoeren met het primaire en secundaire EU-recht feitelijk niet vast, omdat het Hof uiteindelijk tot een andere interpretatie daarvan kan komen dan in de Commissieregels is vervat.

Daarnaast worden nationale autoriteiten ook direct geconfronteerd met zachte bestuurlijke regelgeving van agentschappen, die in de praktijk toch een harde uitwerking kan krijgen. Zo wordt ondanks de erkenning van het formeel niet-bindende karakter daarvan wel degelijk vanuit EU-niveau aangestuurd op bindende werking. Ten aanzien van de financiële agentschappen blijkt dat niet alleen uit de gehanteerde verplichtende bewoordingen, zoals 'de autoriteiten moeten handelen in overeenstemming met' of 'spannen zich tot het uiterste in om aan de richtsnoeren en aanbevelingen te voldoen', maar ook uit het systeem van comply or explain dat de oprichtingsverordeningen voorschrijven, de compliance-tabellen die de agentschappen bijhouden en publiceren en de 'collegiale toetsing' die ze uitoefenen van de bevoegde nationale autoriteiten. Deze omvat onder meer een beoordeling van 'de mate van convergentie die in de toepassing van het Unierecht en in de toezichtpraktijk, daaronder begrepen de op grond van de artikelen 10 tot en met 16 vastgestelde technische reguleringsnormen en technische uitvoeringsnormen, richtsnoeren en aanbevelingen, is bereikt, en de mate waarin de toezichtpraktijk de in het Unierecht vastgestelde doelstellingen bereikt'. ${ }^{43}$ Er wordt dus behoorlijk wat druk uitgeoefend op nationale autoriteiten om te handelen in overeenstemming met de zachte regelgeving. Dit draagt bij aan een diffuse juridische status van agentschapsnormen, waardoor ook nationale benaderingen te dien aanzien nogal uiteen blijken te lopen. ${ }^{44}$

Ook hier geldt dat het antwoord op de vraag hoe wenselijk het is dat lidstaten toegeven aan die druk, afhangt van de mate van democratische legitimatie die de regelgeving in kwestie geniet en hoe noodzakelijk deze wordt bevonden. Dat roept ook vragen op ten aanzien van de betrokkenheid van nationale autoriteiten bij de opstelling ervan, alsook van stakeholders. De oprichtingsverordeningen van de drie financiële agentschappen onderkennen deze noodzaak zeker wel. Zo moeten deze over technische regulerings- of uitvoeringsnormen, richtsnoeren en aanbevelingen met belanghebbende partijen overleggen en hun in redelijke mate de mogelijkheid bieden over voorgestelde maatregelen opmerkingen te maken. Ze houden ook openbare raadplegingen, waarbij het uitgangspunt is dat eerst de potentiële kosten en baten daarvan worden geanalyseerd en dat deze in verhouding moeten staan tot de reikwijdte, de aard en het effect van het richtsnoer of de aanbeveling. ${ }^{45}$ Ook is voorzien in de oprichting van specifieke stakeholdergroe-

43 Art. 30 van de oprichtingsverordeningen. Vgl. ook overweging 26 van de preambule van de EBAverordening: 'Om transparantie te verzekeren en om naleving door de nationale toezichthoudende autoriteiten van die richtsnoeren en aanbevelingen te verbeteren, moet de Autoriteit de mogelijkheid krijgen de redenen waarom die richtsnoeren en aanbevelingen door de toezichtautoriteiten niet worden gevolgd, openbaar te maken.' In meer detail met betrekking tot ESMA, Van Rijsbergen 2014.

44 Van Rijsbergen 2014.

45 Zie bijv. art. 16 van de EBA-oprichtingsverordening. 
pen die evenwichtig moeten zijn samengesteld. ${ }^{46}$ Ten aanzien van de aanname van zachte bestuurlijke (uitvoerings)regelgeving door de Commissie worden in de wetgevingshandelingen die daartoe een opdracht bevatten, vaak ook comitologieprocedures voorgeschreven die de Commissie dan moet volgen. Een belangrijk element in de herziening van de nieuwe aanpak van de Commissie met betrekking tot Europese standaardisatie was juist ook het ontwikkelen van een inclusieve benadering, uitgaande van de gedachte dat steeds meer mensen de gevolgen daarvan zullen ondervinden en dat het succes van de toepassing van Europese normen niet alleen van hun doelmatigheid, maar ook van hun legitimiteit afhangt. ${ }^{47}$ Daartoe voorziet de nieuwe verordening in procedures voor deelname van belanghebbenden aan het normalisatieproces, in een taak voor nationale normalisatie-instituten om het MKB meer bij het normalisatieproces te betrekken en in een specifieke bepaling inzake de deelname van overheden:

'Indien nodig moedigen de lidstaten overheden, met inbegrip van markttoezichtautoriteiten, ertoe aan deel te nemen aan nationale normalisatieactiviteiten die de ontwikkeling of herziening beogen van normen waarom de Commissie (...) heeft verzocht.' (art. 7)

Verder is er ook een mogelijkheid voor lidstaten om bezwaar te maken tegen een norm.

\section{Ter afronding}

De voorgaande bespreking laat zien dat Europese normstelling een steeds diffuser karakter krijgt, zowel in termen van feitelijke herkomst en 'auteurschap' als in termen van juridische aard en status. Lidstaten en nationale autoriteiten worden op een toenemend aantal terreinen niet alleen direct geconfronteerd met een breder scala aan 'zachte' Europese normen, maar ook met 'zachte' publieke en private normen, die uiteindelijk hun beslag kunnen krijgen in harde Europese wetgeving of bestuurlijke regelgeving. Hoewel de bevoegdheid tot bindende Europese wetgeving en bestuurlijke regelgeving op grond van de Europese verdragen formeel aan de Raad, het EP en de Commissie is voorbehouden, kunnen de vastgestelde regels hun oorsprong overduidelijk elders vinden, in normen opgesteld door Europese agentschappen en netwerken alsook private organisaties. Daarnaast blijken agentschappen nu ook harde uitvoeringsregelgeving te mogen aannemen. Gegeven de druk tot naleving van niet alleen de harde, maar ook de zachte bestuurlijke regelgeving is het van belang op te merken dat lidstaten niet helemaal aan de zijlijn staan van deze ontwikkelingen, althans niet wanneer bevoegdheden op grond van wetgevingshandelingen waarbij de Raad is betrokken (wat doorgaans het geval is), aan de Commissie en agentschappen worden toegekend. Nationale parlementen zouden zich in het kader van een subsidiariteitscontrole 
daartegen kunnen verzetten, maar formeel mag deze zich niet uitstrekken tot een proportionaliteitstoetsing. Anderszins is de subsidiariteitscontrole ook beperkt doordat deze formeel op grond van Protocol 2, dat aan het Verdrag van Lissabon is gehecht, alleen voorgestelde wetgevingshandelingen kan betreffen en geen van de andere in deze bijdrage besproken handelingen en instrumenten. Tegelijkertijd echter bieden de aan de bestuurlijke bevoegdheid van de Commissie en agentschappen ten grondslag liggende wetgevingshandelingen heel wat aanknopingspunten voor betrokkenheid, inspraak en controle ten aanzien van de uitoefening daarvan. Of die inclusieve benadering vanuit het oogpunt van democratische legitimatie voldoet, zal nader onderzoek in de toekomst moeten uitwijzen. 